\title{
Comparison of infertility of Varroa destructor in resistant and control colonies of the Iraqi honeybee (Apis mellifera meda)
}

\section{Farzad Moradpour \\ Department of Animal Science, College of Agriculture Engineering, Science, University of Garmian, Kalar, As-Sulaymaniyah, KRG, Iraq}

\begin{abstract}
In the current study, the infertility of Varroa mite was compared in resistant (VSH) and control honeybee colonies at the University of Garmian of Iraq. At each stage, the infestation rate, the percentage of fertile mites, the percentage of infertile mites, the number of cells containing mite eggs, and the number of protonymphs and deutonymphs were counted. Percentages of infestation in resistant and control colonies were $6.2 \pm 0.9$ and $10.9 \pm 1.2$, respectively. There was a statistically significant difference in the percentage of infested cells between the control and resistant groups $(p<0.05)$. Moreover, $56.3 \%$ of the resistant colonies and $37.50 \%$ of the control colonies showed hygienic behaviour (VHS). Resistant colonies showed hygienic behaviour (VHS) regarding the removal of infested pupae and reducing the infestation in colonies compared to control colonies. Mean total infertility in resistant and control colonies were $1.4 \pm 0.4$ and $1.1 \pm 0.3$, respectively. Also, the total mean of protonymphs, deutonymphs, and eggs in resistant and control colonies were $0.06,1.3 \pm 0.4$, and $2.6 \pm 0.8$ in resistant colonies and $0.2,1.3 \pm 0.8$, and $2.6 \pm 1$ in control colonies. The results showed that VSH behaviour in adult bees reduces the rate of infestation by Varroa mites in pupas.
\end{abstract}

Keywords: Iraqi honey bee, Varroa destructor, VSH; SMR

\section{INTRODUCTION}

Today, the European honeybee (Apis mellifera L.) is the dominant species. Due to its lifestyle, abundant pollen and honey production, and faster growth rate, it is widely cultivated in the world (de Guz-

*Corresponding author. Email: farzadmoradpour11@gmail.com man et al., 2002). In addition to the importance of this insect in honey production, it is also one of the most important pollinators of plants doing about $80-85 \%$ of the pollination (Danka et al., 2012). Honeybees are subject to various pests and diseases in many parts of the world. One of these pests is the Varroa mite (Varroa destructor), which causes irreparable damage to the beekeeping industry by the destruction of numerous beehives 
each year (Aumeier, Rosenkranz, 2001). When parasitism is not treated, it causes major damages to A. mellifera colonies, mainly in the countries of temperate climate (Ellis et al., 2004). In some tropical areas of the USA and Brazil, it is not necessary to use pesticides, since honeybees are resistant to $V$. destructor. Several factors such as climate (Moretto et al., 1991), bee race (de Guzman et al., 2007), and the genetics of mite strains are effective in the resistance of honeybees (Strapazzon et al., 2009). Honeybees (A. mellifera) have been selectively bred for resistance to the growth of $V$. destructor population (de Guzman et al., 2007). Selection was based on low percentages of reproductive mites capable of producing a mature daughter (Ellis et al., 2003). The primary mechanism of resistance in these Suppressed Mite Reproduction (SMR) bees is the removal of infested pupae from capped brood cells (Diatemann et al., 2003), so it is suggested that the name be changed to VSH bees, which more accurately identifies the mechanism of resistance as Varroa Sensitive Hygiene (VSH) bees. Resistance to Varroa mites can facilitate the reduction or elimination of the mites by using control methods that reduce the level and the number of $V$. destructor (Ellis et al., 2004). Genetic resistance against Varroa mites may vary in different regions (Elvin et al., 2005). VSH behaviour is probably similar to other forms of hygienic behaviour that honey bees direct towards dead brood, brood infected with bacteria or fungi (Boecking and Spivak, 1999), or brood infested with eggs or larvae of the small hive beetle (Aethina tumida) (Ellis et al., 2003, 2004) or larvae of the greater wax moth (Galleria mellonella) (Corréa-Marques and De Jong, 1998). The genetic expression of VSH varies among different populations of honeybees, and various types of bees may have significant resistance to $V$. destructor as a result of their behaviour (Aumeier, Rosenkranz, 2001).

The VSH bees uncap and remove the infested brood, and the freed adult female mites are usually transferred and removed from the brood (Anderson, Trueman, 2000). Also, the mites may eventually be freed and attacked by bees (Ibrahim, Spivak, 2006). In honeybee colonies having VSH behaviour, adult ones control Varroa mite population by detecting mites laying in the capped brood cells and destroying them. By selecting VSH behaviour, it is possible to find colonies resistant to Varroa. In addition, the queens of these colonies transfer the resistance to Varroa to their progenies through natural mating (de Guzman et al., 2007). The aim of the study was to compare the infertility behaviour (VSH) of Varroa mites in resistant and control colonies in the College of Agriculture, Kifri, University of Garmian, Kalar, As Sulaymaniyah, KRG of Iraq.

\section{MATERIALS AND METHODS}

This research was carried out to compare the infertility of Varroa mites in resistant and control honeybee colonies in College of Agriculture, Kifri, Garmian University, Kalar, As Sulaymaniyah, KRG of Iraq. A random number of 16 colonies were considered as control (group 1) and another 16 colonies as resistant to Varroa mite (group 2). The resistant group did not undergo chemical treatment against the mite during the last four years. Also, the colonies with $10-22 \%$ infestation were used as source colonies of infestation. At the start of the experiment, one frame from each colony, with 600 old worker brood, was randomly transferred to the infested hives for 48 hours for the Varroa mites to get into and reproduce in brood cells. After 48 hours and when the brood cells were capped, the test frames were returned to their own colonies. On the first day (day 0 ) of the experiment and before returning the frames to their own colonies, the percentages of initial infestation were determined. A square space containing 400 pupae cells was made in the middle of the test frame. Then, using forceps, 200 pupae cells around the square space were uncapped along a line and then evaluated. The age of uncapped larvae cells, the number of mother mites, daughter mites, and mite eggs were counted by microscope to determine the percentage of initial infestation. The test frames were returned to the resistant and control colonies and the mites were allowed to enter the brood cells to feed and reproduce along 
with the growing and developing host pupae. On days 7 and 10, a number of 200 brood cells located around the square space were uncapped and, using a microscope, the mother mites, daughter mites, and mite eggs were counted.

The rate of VSH behaviour in the infested cells was estimated by measuring the initial infestation (day 0) and final infestation (day 10) based on the following formula (Kirrane et al., 2015):

Removal infested brood $=\frac{(\text { Initial infestation }- \text { Final infestation })}{\text { Initial infestation }} \times 100$.

The infertility of $V$. destructor was determined by counting the number of female mites that entered the brood cell but did not have baby and egg cell on days 7 and 10 of the experiment. A foundress Varroa was considered to be nonreproductive when no progeny was produced in the cells. For this investigation of mite reproduction, only single infested brood cells (one foundress mite) 7-10 days post capping (pupa, brown head and black eyes) were evaluated. At the purple-eye stage of the bee (7-9 days post capping), normal reproducing mites had at least one deutonymph. At the black-eye stage (10-12 days post capping), normally reproducing mites had at least one deutonymph. In pupae with black eyes (10-12 days post capping), reproduction mites normally have at least one adult daughter mite. Infested pupae with no or only younger stages of Varroa offspring are therefore counted as containing non-reproductive mites.

The stages of brood growth and the mite offspring that were transfered to the brood and reproduced are shown in Fig. 1. At each stage, the reproduction of mite can be studied. In fact, the age of worker pupae is a guide.

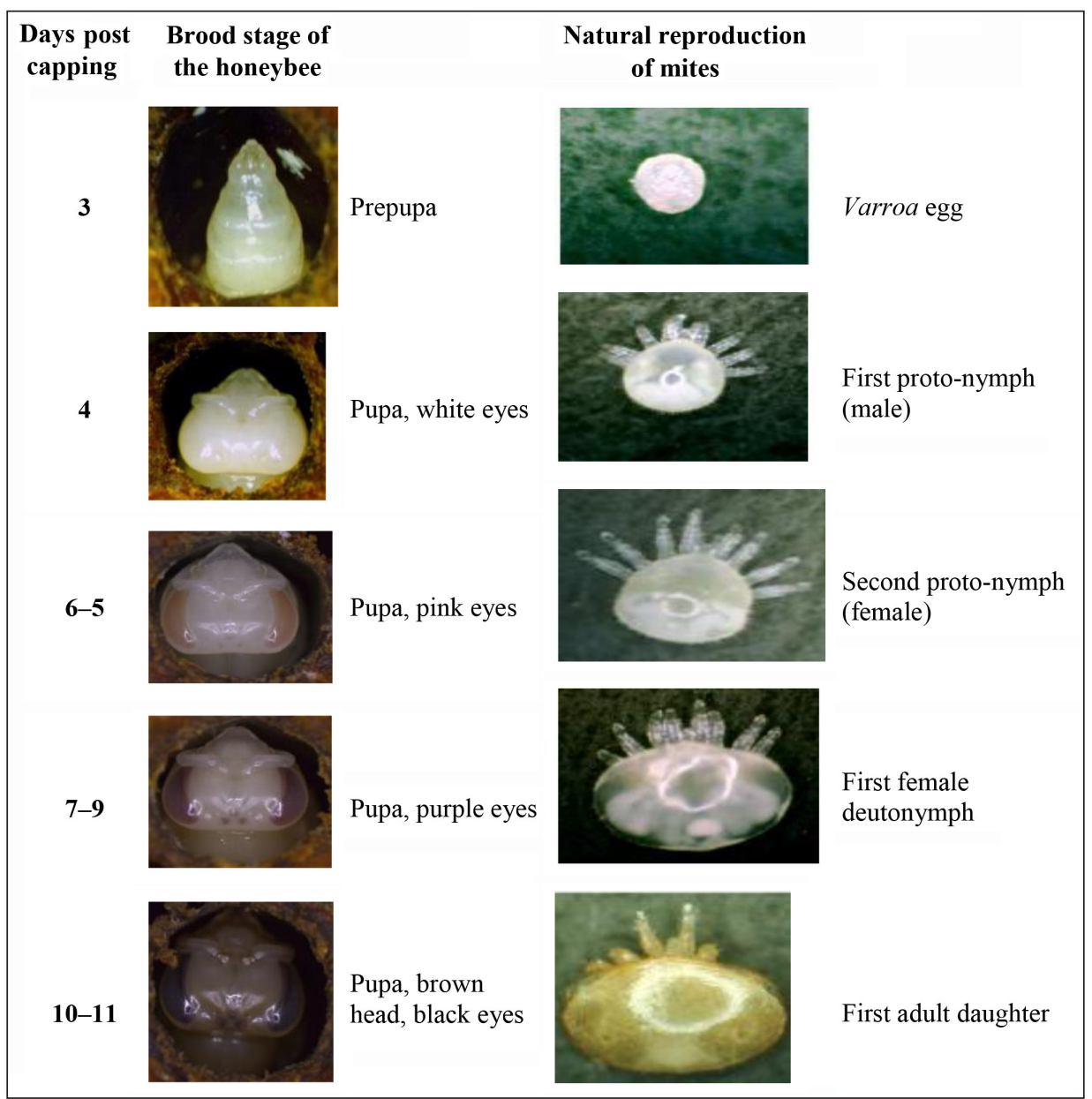

Fig. 1. The stages of honeybee brood and mite offspring in capped environment 


\section{RESULTS AND DISCUSSION}

In the present study, in order to investigate the reproduction in the experimental colonies, 8757 and 8063 pupae were uncapped with forceps from the resistant and sensitive colonies, respectively, during autumn 2015 and the number of mother mites, eggs, and their infants were counted on days 0,7 , and 10 . Various parameters of infestation resulting from the analysis of the data in the resistant and control colonies are shown in Table.

Infestation with Varroa in resistant and control colonies was $6.2 \pm 0.9$ and $10.9 \pm 1.2$ respectively, which suggests a significant difference $(p<0.05)$. This is in agreement with the findings of other authors, who reported the percentages of infested cells in Russian and Italian bees as $6.02 \pm 1.14$ and $14.42 \pm 3.1$, respectively (Kirrane et al., 2015; Harris, 2007). On the other hand, these percentages exceed the findings of Harbo and Harris (2001), who reported the percentages of Varroa-infested cells in Louisiana SMR and control bees as $2.2 \pm 0.8$ and $9 \pm 0.9$, respectively. In reproductive mites, infertility happens when there is no progeny. The average infertility in the resistant and control colonies was $1.4 \% \pm 0.4$ and $1.1 \% \pm 0.3$, respectively, showing no significant difference at $p \leq 0.05$ (Fig. 2). These findings do not agree with those of Kirrane and co-author (2015), who recorded infertility in Italian and Russian colonies as $4.4 \pm 1.3$ and $13.1 \pm 1.8$, respectively, while they are in line with the studies reported by Harbo and Harris (2005), who reported $1.2 \pm 0.2$ and $1.3 \pm 0.2$ of infertility in SMR and control bees, respectively.

Also, in the resistant colonies, total averages of eggs, protonymphs, and deutonymphs were $0.06 \pm 0.02,1.3 \pm 0.4$, and $2.6 \pm 0.8$, respectively, whereas in the control colonies these were $19 \pm 0.6,3.1 \pm 0.8$, and $4.6 \pm 1$, respectively. In fact, there was a statistically significant difference in the number of protonymphs between the control and resistant group ( $p$-value $=0.004)$, while the difference in the number of deutonymphs was not significant. These findings of the study agree with those of Carneiro et al. (2014) in Brazil, who estimated total averages of deutonymphs and protonymphs as $1.6 \pm 0.1$ and $1.6 \pm 0.1$, respectively. Moreover, $56.3 \%$ and $37.5 \%$ VSH of resistant and control colonies showed a high level of Varroa hygienic behaviour (VSH), respectively, but not significant (Fig. 3). This is close to Harbo and Harris (2005), who recorded the percentage of the reduction in the infested cells in VSH and control colonies as $55 \pm 12$ and $13 \pm 25$, respectively. Findings suggest that VSH bees eliminate more of Varroa-infested capped pupae from the cells compared to the control group and therefore reduce the infestation. In fact, VSH colonies reduce the total infestation by $56 \%$ and this cut in the number of infested pupae of VSH bees is similar to the findings of previous studies (Elvin et al., 2005).

Table. Parameters of infestation in resistant and control colonies

\begin{tabular}{ccc}
\hline Parameters & Resistant & Control \\
\hline Number of test colonies & 16 & 16 \\
\hline Total number of cells examined & 8757 & 8063 \\
\hline Number of cells examined per colony & $535.3 \pm 26.1$ & $510.2 \pm 34.3$ \\
\hline The average of infertility of mite & $1.4 \pm 0.4$ & $1.1 \pm 0.3$ \\
\hline The average of protonymph & $1.3 \pm 0.4$ & $3.1 \pm 0.8$ \\
\hline The average of deutonymph & $2.6 \pm 0.8$ & $4.6 \pm 1$ \\
\hline The percentage of infested cells & $6.2 \pm 0.9$ & $10.9 \pm 1$ \\
\hline VSH+ & $\% 56.3$ & $\% 37.5$ \\
\hline
\end{tabular}




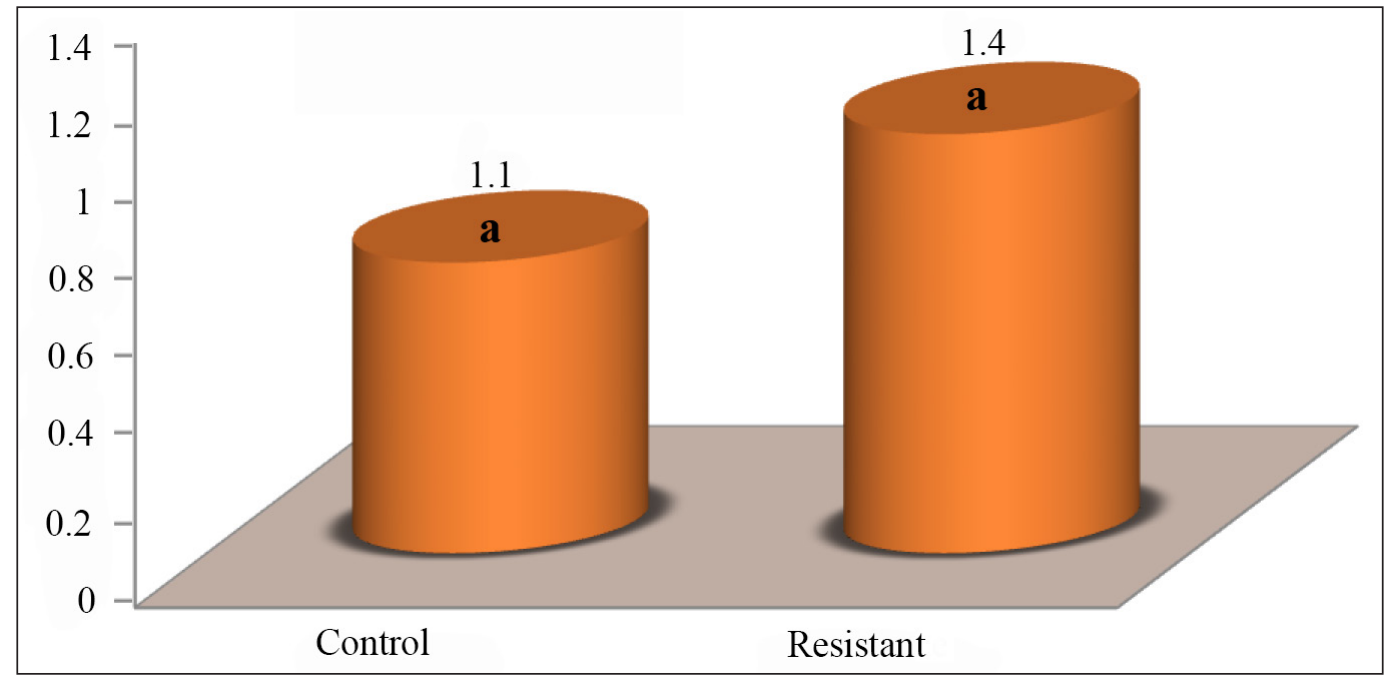

Fig. 2. Average of infertility in resistant and control colonies

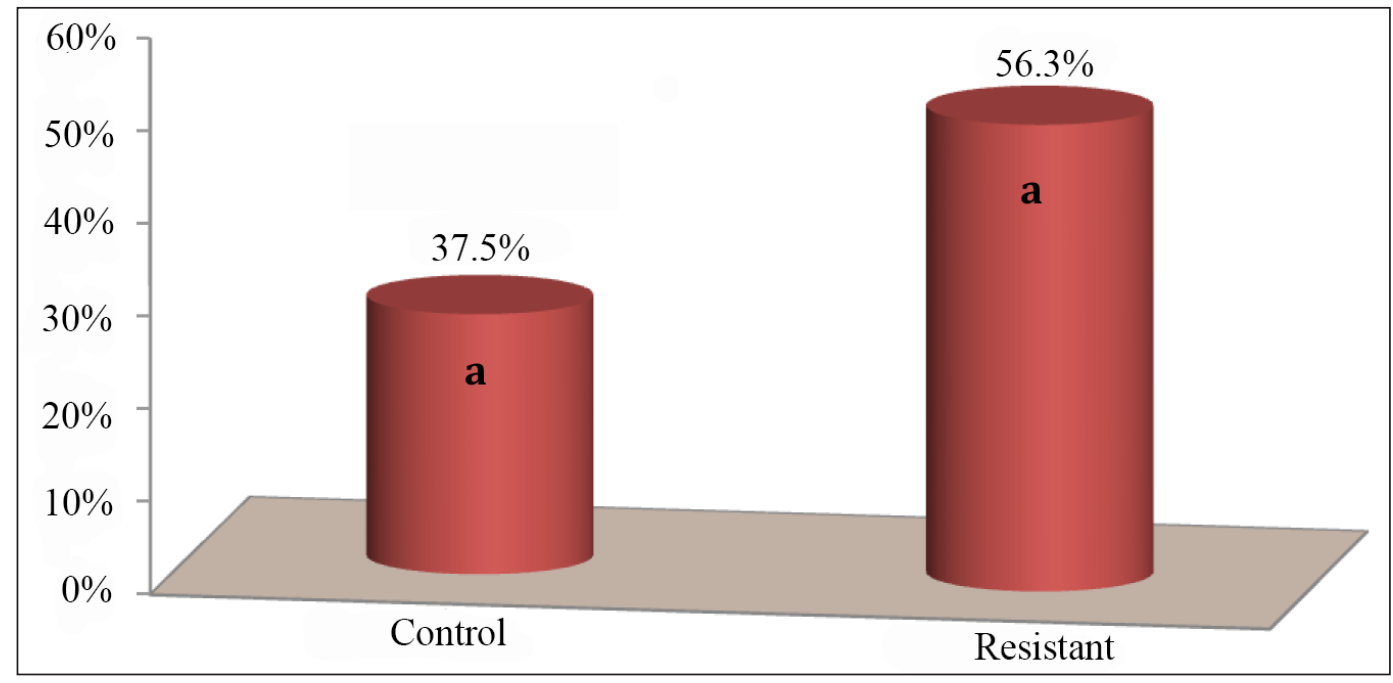

Fig. 3. Average VSH+ in resistant and control colonies

\section{CONCLUSIONS}

The findings show that high hygiene behaviour (VSH) in resistant colonies helped removing the mite from the infested cells and reduced the growth population and reproduction of Varroa in pupa cells $(p>0.05)$. The resistant bees (VSH) had a stronger sense of smell in diagnosis of infestation by Varroa and removing mites from infested pupae compared to control group. Also, no significant difference was found between resistant and control groups regarding infertility, which can also result in the reduc- tion of infestation levels in the experimental colonies. In addition, the percentage of infestation was different in the two groups, which can be due to differences in hygienic behaviour in experimental colonies or, possibly, the differences in the percentage of infested colonies. The study also confirms previous research suggesting a critical threshold for the percentage of infestation in pupae by $V$. destructor - resistant bee health behaviour.

Received 21 July 2020 Accepted 17 August 2020 


\section{References}

1. Anderson DL, Trueman JWH. Varroa jacobso$n i$ (Acari:Varroidae) is more than one species. Exp Appl Acarol. 2000; 24: 165-89.

2. Aumeier P, Rosenkranz P. Scent or movement of Varroa destructor mites does not elicit hygienic behaviour by Africanized and Carniolan honey bees. Apidologie. 2001; 32(3): 253-63.

3. Boecking O, Spivak M. Behavioral defenses of honey bees against Varroa jacobsani Oud. Apidologie. 1999; 30: 141-58.

4. Carneiro FE, Barroso GV, Strapazzon R, Moretto G. Reproductive ability and level of infestation of the Varroa destructor mite in Apis mellifera apiaries in Blumenau. State of Santa Catarina Brazil. Acta Scientiarum. Biological Sciences. 2014; 36(1): 109-12.

5. Correa-Marques MH, de Jong D. Uncapping of worker bee brood, a component of the hygienic behavior of Africanized honey bees against the mite Varroa jacobsoni Oudemans. Apidologie. 1998; 29(3): 283-9.

6. Danka RG, de Guzman LI, Rinderer TE, Sylvester HA, Wagener CM, Bourgeois AL, Harris JW, Villa JD. Functionality of Varroa-resistant honey bees (Hymenoptera: Apidae) when used in migratory beekeeping for crop pollination. J Econ Entomol. 2012; 105(2): 313-21.

7. de Guzman LI, Rinderer TE, Stelzer JA, Beaman LD, Delane GT, Harper C. Hygienic behavior by honey bees from far-eastern Russia. Am Bee J. 2002; 142: 58-60.

8. de Guzman LI, Rinderer TE, Frake AM. Growth of Varroa destructor (Acari: Varroidae) populations in Russian honey bee (Hymenoptera: Apidae) colonies. Ann Entomol Soc Am. 2007; 100(2): 187-95.

9. Dietemann V, Pflugfeder G, Anderson D, Charrière JD, Chejanovsky $\mathrm{N}$, Dainat $\mathrm{B}$, de Miranda J, Delaplane K, Dillier FX, Fuch S, Gallmann P, Gauthier L, Imdorf A, Koeniger N, Kralj J, Meikle W, Pettis J, Rosenkranz P, Sammataro D, Smith D, Yañez O, Neu- mann P. Varroa destructor research avenues towards sustainable control. J Apic Res. 2012; 51: 125-32.

10. Ellis JD, Richards CS, Hepburn HR, Elzen PJ. Oviposition by small hive beetles elicits hygienic responses from Cape honey bees. Naturwissenschatten. 2003; 90: 532-5.

11. Ellis JD, Delaplane KS, Richards CS, Hepburn R, Berry JA, Elzen PJ. Hygienic behavior of Cape and European Apis mellifera (Hymenoptera: Apidae) toward Aethina tumida (Coleoptera: Nitidulidae) eggs oviposited in sealed bee brood. Ann Entomol Soc Am. 2004; 97(4): 860-4.

12. Elvin CM, Carr AG, Huson MG, Maxweel JM, Pearson RD, Vuocolo T, Liyou NE, Wong DCC, Meritt DG, Dixon NE. Synthesis and properties of crosslinked recombinant pro-resilin. Nature. 2005; 437: 999-1002.

13. Ibrahim A, Spivak M. The relationship between hygienic behavior and Suppressed of mite reproduction as honey bee (Apis mellifera) mechanisms of resistance Varroa destructor. Apidologie. 2006; 37: 31-40.

14. Harris JW. Bees with Varroa Sensitive Hygiene preferentionally mite infested pupae aged $<$ five days post capping. J Apic Res. 2007; 46(3): 134-9.

15. Harbo JR, Harris JW. Resistance to Varroa destructor (Mesostigmata: Varroidae) when mite-resistant queen honey bees (Hymenoptera: Apidae) were free-mated with unselected drones. J Econ Entomol. 2001; 94(6): 1319-23.

16. Harbo JRJ, Harris JW. Suppressed mite reproduction explaned by the behavior of adult bees. J Apic Res. 2005; 44(1): 21-3.

17. Kirrane MJ, de Guzmam L, Holloway B, Frake AM, Renderer TE, Whelen PM. Phenotypic and genetic analysis of the Varroa sensitive hygienic traits in Russian honey bee (Hymenoptera: Apidae) colonies. Plosone. 2015; 11: 66-72.

18. Moretto G, Goncalves LS, De Jong D, Bichuette MZ. The effects of climate and bee race 
on Varroa jacobsoni Oud infestations in Brazil. Apidologie. 1991; 22(3): 197-203.

19. Strapazzon R, Carneiro FE, Guerra JR, Guerra JCV, Moretto G. Genetic characterization of the mite Varroa destructor (Acari: Varroidae) collected from honey bees Apis mellifera (Hymenoptera, Apidae) in the State of Santa Catarina, Brazil. Genet Mol Res. 2009; 8(3): 990-7.

\section{Farzad Moradpour}

VARROA DESTRUCTOR NEVAISINGUMO PALYGINIMAS ATSPARIOSE IR KONTROLINE்SE IRAKO BIČIŲ (APIS MELLIFERA MEDA) KOLONIJOSE

\section{Santrauka}

Irako Garmiano universiteto tyrime buvo palygintas Varroa erkių nevaisingumas atspariose (VSH) ir kontrolinėse bičių kolonijose. Kiekviename etape buvo skaičiuotas užkrètimo dažnis, vaisingų erkių procentas, nevaisingų erkių procentas, ląstelių, ku- riose yra erkių kiaušiniai, protonimfų ir deutonimfų skaičius. Užkrètimo procentas atspariose ir kontrolinėse kolonijose buvo atitinkamai 6,2 \pm 0,9 ir 10,9 $\pm 1,2$. Tarp kontrolinių ir atsparių grupių buvo statistiškai reikšmingas užkrèstų ląstelių procentinis skirtumas $(p<0,05)$. Be to, 56,3\% atsparių kolonijų ir 37,5 \% kontrolinių kolonijų užfiksuotas higieniškas elgesys (VSH). Palyginti su kontrolinemis kolonijomis, atsparios kolonijos higienišką elgesị parodè (VSH), kai buvo pašalintos užkrèstos pupos ir sumažèjo kolonijos užkrètimas. Vidutinis bendras nevaisingumas atspariose ir kontrolinèse kolonijose buvo atitinkamai 1,4 \pm 0,4 ir $1,1 \pm 0,3$. Bendras protonimfų, deutonimfų ir kiaušinių vidurkis atspariose ir kontrolinèse kolonijose buvo atitinkamai 0,06, 1,3 $\pm 0,4,2,6 \pm 0,8$ ir 0,2, $1,3 \pm 0,8,2,6 \pm 1$. Rezultatai rodo, kad suaugusių bičių VSH elgesys sumažina lèliukių užkrètimo Varroa erkèmis dažnį.

Raktažodžiai: Irako bitès, Varroa destructor, VSH, SMR 